\title{
ON THE BIOLOGY OF MYTILICOLA INTESTINALIS (STEUER)
}

\author{
By A. R. Hockley \\ Department of Zoology, University College, Southampton
}

(Text-figs I-3)

INTRODUCTION

The copepod parasite Mytilicola intestinalis was first described by Steuer (I902) from the gut of Mytilus galloprovincialis (Lam.) in the Gulf of Trieste. Monod \& Dollfus in 1932 recorded the same species from M. edulis from Marseilles. In 1939 the parasite was first recorded on the German North Sea coast by Caspers near Cuxhaven, and in 1947 by Ellenby from Blyth, Northumberland. It is now widespread along the English south coast in M. edulis, but the distribution still shows some irregularities that are discussed in this paper.

I am grateful to Prof. J. E. G. Raymont for facilities at University College, Southampton, and for the use of a research table at Plymouth; to Mr F. S. Russell, F.R.S., and the staff of the Plymouth Laboratory of the Marine Biological Association for their assistance; and to Dr D. P. Wilson for facilities to collect at Exmouth. Dr H. A. Cole and Mr J. N. R. Grainger have kindly given me information from their papers not yet published. Dr D. J. Crisp and Dr H. G. Stubbings have assisted by sending me several samples of mussels, and I am grateful also for information received from several other friends named in the text.

\section{DESCRIPTION}

Steuer's description includes the following points. Length: male about $4 \mathrm{~mm}$., female about $8 \mathrm{~mm}$. Body elongated and worm-like. Thoracic segments with paired dorsal processes. Segmentation of abdomen incomplete. Genital openings paired, female carrying two long, narrow egg-sacs, in which eggs are arranged with some regularity. These features are shown in Fig. I. The head carries a median eye, first antennae of four joints, and second antennae of three joints, the last forming a hook. Lateral to the maxillary base Steuer notes the presence of a soft pocket in the body wall receiving the tip of the antenna. I am unable to recognize this as a permanent structure.

The nomenclature of the mouthparts given by Steuer (1902) was revised by him (1905), when he recognized the opening of the shell gland (excretory 
gland), but he continued to follow Claus's older work and named the appendage with the excretory gland as Ist maxilliped. Claus (1895) had agreed with Giesbrecht and Hansen to call this appendage the maxilla, preceded by a maxillule and followed by maxillipeds. Wilson (1910) confirmed this arrangement for the parasitic types.

Dollfus (1932) followed Wilson in the main terminology, but criticized the identification of the mandibles by Steuer. It is clear that Mytilicola lacks one

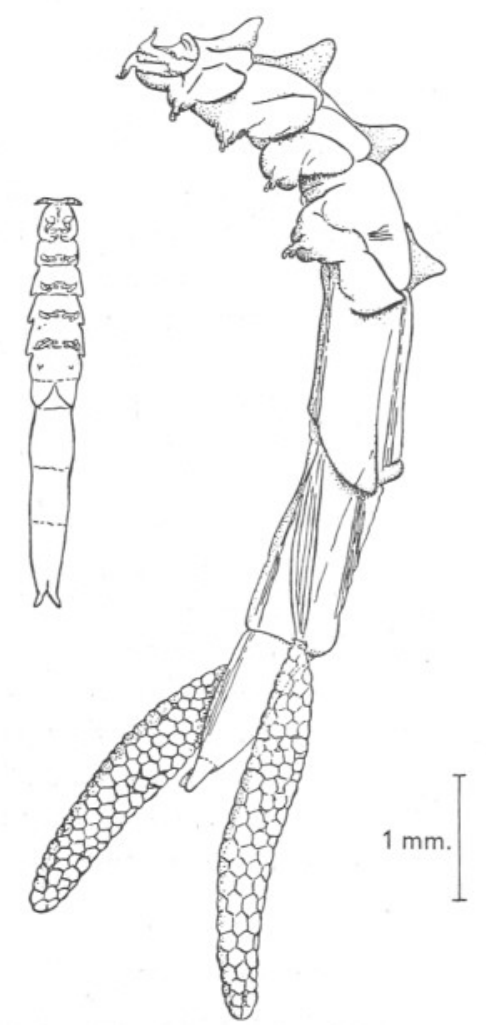

Fig. I. Mytilicola intestinalis, adult male (left) from the ventral aspect, and female (right) with egg-sacs in left dorso-lateral view. The dorso-lateral processes are shown, by which the animal presses the ventral surface with appendages against the opposite wall of the host's intestine.

of the characteristic pairs of appendages, and Steuer thought this to be the post-mandibular pair. Dollfus, by a comparison with Lichomolgus, Ergasilus, Panaietis and Trochicola, has shown that in all probability the mandibles are lost and the first mouthparts present are the maxillules. My examination of the larval stages supports Dollfus's conclusion (see below, and Fig. 3).

My interpretation of the head of the female is shown in Fig. 2A. Whole specimens have been mounted direct in polyvinyl lactophenol and lignin pink, 
and also dissections have been made with the Labgear Harding micromanipulator. The base of the maxillule is deeply embedded in the head, and the projecting part fits closely in a depression of the anterior margin of the maxillary base. The maxillules are wide apart, and their movements contribute only slightly to the feeding process. They may assist in movement through the gut of the host, or in maintaining a hold while the antennae are released and moved forward.

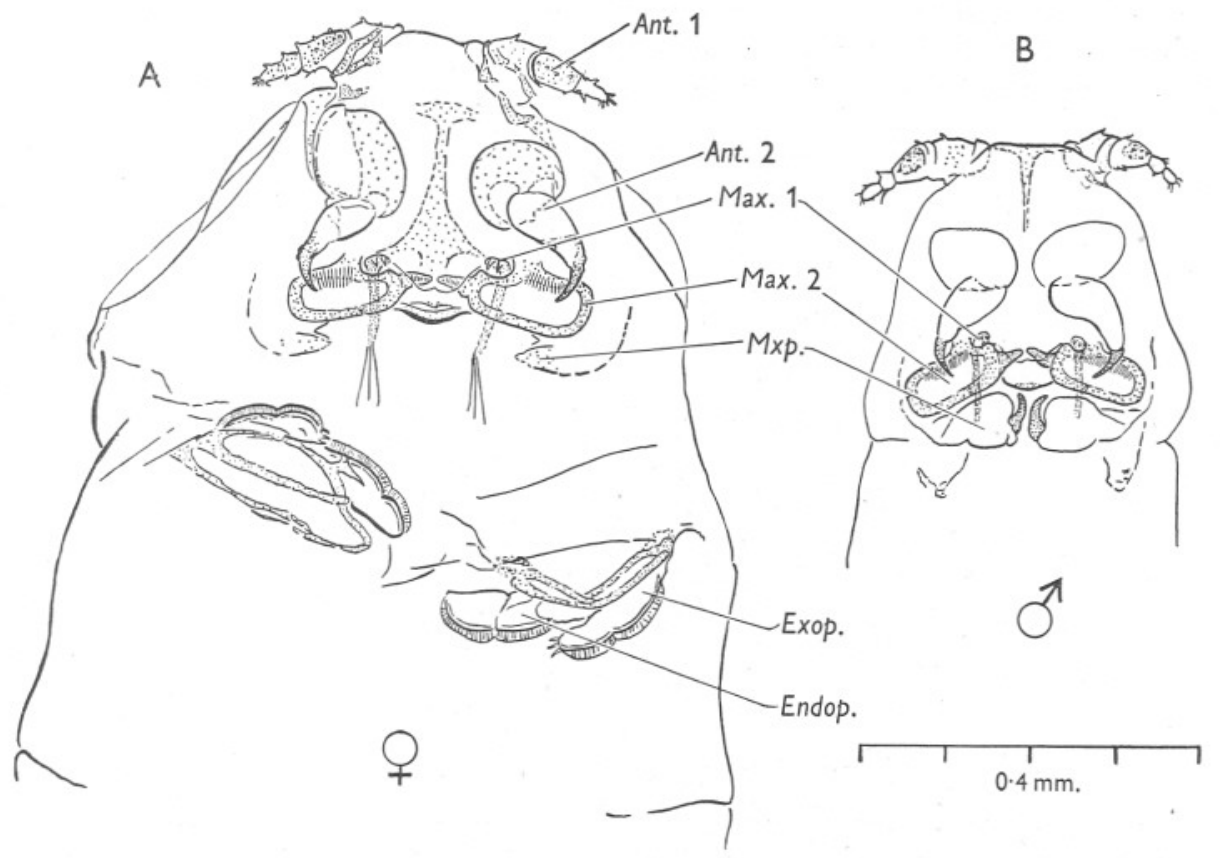

Fig. 2. Mytilicola intestinalis. A, head and first free thoracic segment of a mature female. B, the head of a male, in ventral view. Ant. I, antennule; Ant. 2, antenna; Max. I, maxillule; Max. 2, maxilla; Mxp., maxilliped, vestigial in the female. In both sexes the upper and lower lips are shown, the former covering the inner ends of the maxillae. Exop., exopodite, and Endop., endopodite of the typical thoracic limb.

The base of the maxilla is thickly sclerotized. On the posterior border it carries the aperture of the excretory gland. The inner side of the base carries a pointed projection bearing minute serrations. This part of the maxilla meets its counterpart of the opposite side and is used to push food into the mouth. As noted above, the anterior margin of the maxilla is hollowed around the maxillule, and lateral to this it bears a row of ridges which lie adjacent to the hook of the antenna. Each ridge projects at its posterior end, forming a small tooth. It appears that these structures also assist in maintaining position in the host. Behind the maxillae is a pair of quite vestigial maxillipeds.

The upper lip is a well-defined structure, overlapping the inner processes of 
the maxillae. The lower lip is less prominent, but it forms a firmly sclerotized line between the maxillary bases.

In the male, Fig. 2B, the head appendages follow closely the structure described for the female. The maxillipeds are, however, well developed. Each has a large swollen base, and a strong hook curved in a forward direction.

The first four pairs of thoracic feet are similar in both sexes. The base is a double chitinous ring, carrying exopodite and endopodite each of two joints. Their outer edges carry a ridge of thin cuticle with some vertical striation which may easily be mistaken for fine hairs. A few small spines and bristles occur on each foot. The fifth pair of feet are reduced to short bristled pegs.

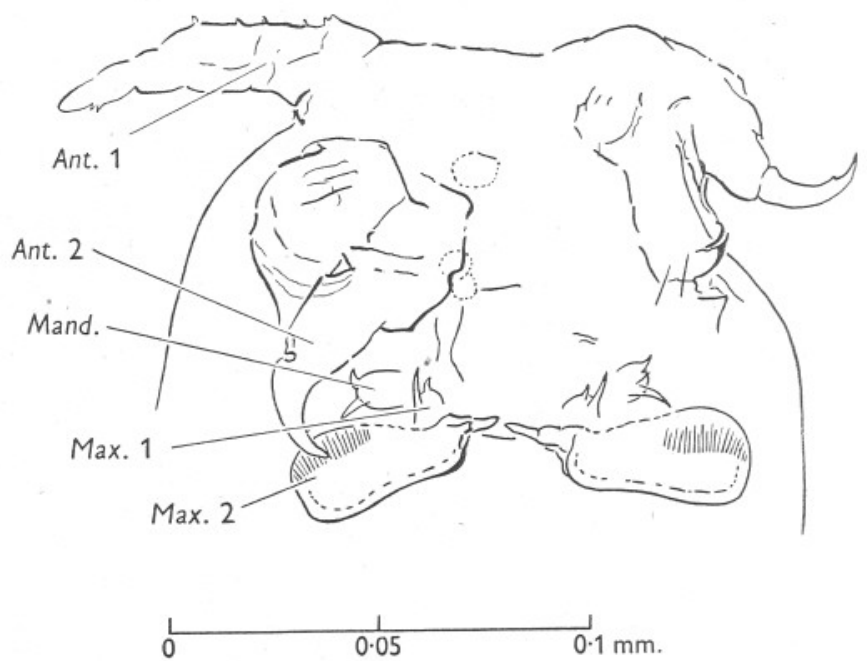

Fig. 3. Mytilicola intestinalis, head of a larva of the second parasitic instar, showing the mandible (Mand.) which is subsequently lost. The relationship between the maxillule (Max. I) and maxilla (Max. 2) is very similar to that of the adult.

\section{HABITAT AND LIFE History}

The worm-like parasites lie in the recurrent intestine or rectum of Mytilus edulis, but not in the direct intestine or style sac. Generally they have a bright red colour and are easily seen, but occasionally quite active individuals are found with no colour. The female parasite occupies most of the lumen of the gut and presses the ventral surface close against the wall with the aid of the paired dorsal thoracic processes. Between these processes the main stream of the host's food is allowed to pass. In the intact gut I have seen little activity, but as soon as contact with the gut wall is lost the parasite begins vigorous peristaltic contractions. If only the posterior half is exposed the parasite can quickly crawl farther into the gut, but when fully exposed its power of locomotion is greatly reduced. At such times a frequent upward flick of the 
head is noticed, and it is probable that such a movement in the normal environment would ensure that some of the food mass passed to the oral surface of the parasite. Adult females appear to be always orientated with the head towards the oncoming food, but the smaller males seem to move about more freely. Probably the male maxilliped is used in pairing. Despite the large numbers of fresh specimens examined, pairing has never been observed, and it is safe to assume that the association is quite temporary.

When a group of mussels is kept in the laboratory for 2 or 3 days the parasites may move down the gut until the egg-sacs protrude from the anus, but no adult parasite has been seen to leave the host. Females may be found with the eggs in various stages of development, but they are seldom found with eggs ready to hatch. Parasites removed from the host may retain the egg-sacs even after all the eggs have hatched, but they are easily detached at any stage. It seems probable that only mechanical forces in the host gut cause the shedding of egg-sacs, and this not long before hatching.

The youngest egg-sacs, with an opaque pink colour, were removed and cultured in beakers containing I50 c.c. Plymouth 'outside' sea water. No special filtration or sterilization of the water was found necessary. Slow aeration was maintained and the larvae were fed with cultured Chlamydomonas. The average temperature was $18^{\circ} \mathrm{C}$.

Under these conditions the embryos develop a translucent brown tint, with a prominent red eye in each. Hatching occurs in about 7 days, and the nauplius and metanauplius instars are passed on the eighth day. These two larvae show a strong positive phototropism, which was seen by all previous workers, who also noted that the reaction is lost at the third instar (Ist copepodid). The copepodid is an active swimming stage with two pairs of biramous thoracic limbs. Its movement in culture vessels is occasional or spasmodic, and since it is markedly more dense than the water, it tends to swim in the lower part of the vessel. This may be important among factors limiting the distribution.

The first copepodid is the infective stage, and although Pesta (1907) failed in his efforts to infect mussels, Caspers (1939) and Grainger (private communication) found no difficulty. The present author has reared many larvae, and carried out the infection of a mussel measuring II mm. long. From this host twenty-two fourth- and fifth-instar parasites were recovered after 3 weeks. This probably does not reflect a normal growth rate, for such a heavy infection of a small host is unusual, and the copepodids may have had only a minimum of food.

Caspers figured three parasitic instars before the adult form, and no attempt has been made here to check his observations. Dollfus has noted that previous figures of the larvae do not show the detail needed to decide the fate of the mandible and maxillule. I have examined all the earlier larvae, and Fig. 3 shows the head of a fifth-instar (second parasitic) larva. Although their cuticle is but 
slightly thickened, it is possible to discover at this stage both pairs of appendages, and therefore to confirm that the mandible is the appendage missing from the adult head.

\section{DisTRIBUTION}

Altogether over a thousand mussels have been examined, by opening the whole intestine of each specimen, from sites extending from Kent to Cornwall. In the neighbourhood of Southampton mussels have been examined at all times of the years I948-50, and no significant seasonal variation was detected. On each occasion females with egg-sacs were present. Males were always the more numerous, a typical sample yielding I 82 males: 53 females. Larval stages were seldom found. Although some may have been overlooked because of their small size, I believe it is safe to infer that the time occupied by the three larval parasitic instars is short when compared with the average span of adult life.

In many places it was difficult to secure an adequate sample of mussels, but Table I shows that the absence of the parasite cannot be assumed at any of these sites.

Further reports have been received, and are gratefully acknowledged as follows:

Whitstable, Kent, the parasite is common (Dr G. E. Newell)

Littlehampton, Sussex, mussels are not numerous but the parasite is present (Mr E. W. Baxter)

Poole Harbour, Dorset, very abundant I950 (Dr H. A. Cole)

Falmouth Harbour, Cornwall, present I949 (Dr H. A. Cole)

Teignmouth, Devon, absent 1949 (Dr H. A. Cole)

Fowey, Cornwall, absent I949 and I950 (Dr H. A. Cole)

Conway, Caernarvonshire, absent (Dr H. A. Cole)

Co. Cork, Eire, the parasite is common (Mr J. N. R. Grainger).

\section{DisCUSSION}

\section{Estuarine and Marine Environments}

Caspers has suggested that the parasite may be indicative of polluted water, being particularly prevalent in the shallow waters of estuaries. He does not give a detailed description of his sites, but Neuharlingersiel and Karolinensiel would appear from the map to be protected shallows and not true estuaries, and these areas he found to be heavily infested. Other areas such as Norddeich and Busum appear to be similar, yet the parasite was absent. From all the more exposed situations and deeper waters he obtained no Mytilicola. The density of the population in the infected areas led Caspers to suppose that the parasite was not a recent immigrant, but had been previously overlooked.

Ellenby, reporting a heavy infestation at Blyth in I946, was convinced that the parasite was newly arrived, for mussels had been regularly examined 
from that area over a period of some years. The same experience obtains at Southampton, where the Woolston mussels were at least relatively free until I948. Seventy parasites were then recovered from twenty-four hosts in a sample of thirty-nine mussels. This density of population shows that the parasite is able to establish itself rapidly in the muddy and often shallow waters of

Table I. South Coast Distribution of Mytilicola intestinalis

\begin{tabular}{|c|c|c|c|}
\hline Locality & $\begin{array}{l}\text { No. of } \\
\text { Mytilus } \\
\text { opened }\end{array}$ & $\begin{array}{l}\text { No. } \\
\text { infected }\end{array}$ & Type of site and remarks \\
\hline Birchington, Kent & I8 & 9 & Mussel bed offshore \\
\hline Bognor, Sussex & I6 & IO & Open shore \\
\hline $\begin{array}{l}\text { Langstone Bridge, } \\
\text { Hayling Island }\end{array}$ & 5 & 4 & Attached to stones in mud; protected \\
\hline $\begin{array}{l}\text { Horsey Island, Ports- } \\
\text { mouth Harbour }\end{array}$ & 5 & I & Attached to stones in wall; protected \\
\hline Sandown, Isle of Wight & I9 & 12 & Low down on pier. Flat shore. \\
\hline Titchfield, Hants & 78 & 60 & $\begin{array}{l}\text { Mussel bed offshore, protected by } \\
\text { island }\end{array}$ \\
\hline Hook Bungalow, Hants & 9 & 9 & Stones on flat shore \\
\hline $\begin{array}{l}\text { Woolston, Southampton } \\
\text { (River Itchen) }\end{array}$ & 39 & 24 & $\begin{array}{l}\text { On pier and from the ground; } \\
\text { estuarine }\end{array}$ \\
\hline $\begin{array}{l}\text { Eling, Southampton } \\
\text { (River Test) }\end{array}$ & 50 & I9 & Wreck on muddy bottom near L.w. \\
\hline Milford-on-sea, Hants & 8 & 6 & On groynes; exposed \\
\hline Barton-on-sea, Hants & 5 & 0 & On groynes; exposed \\
\hline $\begin{array}{l}\text { Mudeford, Christchurch } \\
\text { (River Avon) }\end{array}$ & 45 & I6 & Concrete blocks on shore \\
\hline Sandbanks, Poole Harbour & 3 & 2 & Protected \\
\hline Studland Bay, Dorset & I3 & I3 & On low rocks \\
\hline \multicolumn{4}{|l|}{ Exmouth, Devon: } \\
\hline (a) On quay wall & 50 & 0 & Vertical surface, strong current \\
\hline (b) Bull Hill Bank & 100 & I & Extensive mussel bed in estuary \\
\hline $\begin{array}{l}\text { Goodrington Sands, } \\
\text { Paignton }\end{array}$ & 36 & 2 & From flat rocks among sand \\
\hline \multicolumn{4}{|l|}{ Brixham, Devon: } \\
\hline (a) On floating pontoon & I34 & I3 & From sides and under \\
\hline (b) On sea bed & 18 & $\mathrm{I}$ & Few mussels only under rocks \\
\hline $\begin{array}{l}\text { Steer Point, River Yealm, } \\
\text { Devon }\end{array}$ & 50 & 46 & Very protected bed in estuary \\
\hline Cattewater, Plymouth & II3 & 4 & $\begin{array}{l}\text { In cracks of quay wall. Protected and } \\
\text { estuarine }\end{array}$ \\
\hline \multicolumn{4}{|l|}{ Plymouth Sound: } \\
\hline (a) Rum Bay & 23 & I & On rocks near H.w. \\
\hline (b) Pier piles & 107 & 5) & \\
\hline $\begin{array}{l}\text { (c) Drake's Island } \\
\text { (d) Promenade wall }\end{array}$ & 50 & I & All on nearly vertical surfaces \\
\hline $\begin{array}{l}\text { (d) Promenade wall } \\
\text { (e) West Hoe }\end{array}$ & $\begin{array}{l}\text { I5 } \\
20\end{array}$ & $\begin{array}{l}\text { I } \\
\text { I }\end{array}$ & \\
\hline Neal Point, River Tamar & 77 & 70 & Specimens dredged in estuary \\
\hline $\begin{array}{l}\text { Anthony Quay, River } \\
\text { Lynher }\end{array}$ & 53 & 49 & $\begin{array}{l}\text { From stones in mud. Protected } \\
\text { estuary }\end{array}$ \\
\hline Cawsand Bay, Cornwall & 20 & $\circ$ & Small specimens on rocks near H.w. \\
\hline
\end{tabular}

harbours and estuaries. It is unlikely that such an obvious parasite would have been overlooked for long at Plymouth, yet the mussels now in the Tamar and Lynher estuaries show an average of eleven parasites per host.

Ellenby noted that the mussels of the only bed of purely marine character available in his area, at Holy Island, contained no Mytilicola. This agreed with 
Caspers's observations. The records given here show that Mytilicola is quite capable of parasitizing mussels of a purely marine environment, either on open shores (Bognor, Sandown, Studland), or in more protected places (Titchfield). In fact from all the marine areas examined negative results were obtained only at Barton-on-Sea, Hants, and Cawsand Bay, Cornwall. At the former site the sample was obviously inadequate, and Mytilus was itself barely established on the shore. At Cawsand the mussels were better established, but they were not numerous and individuals were somewhat stunted in growth.

Whatever factors may limit the distribution of Mytilicola intestinalis, the species is not restricted to estuarine environments, although these may provide optimum conditions for its growth. In view of the power of rapid colonization here shown, it seems likely that those few estuaries that remain free will not for long maintain their immunity.

\section{The Invasion of New Areas}

Established beds of Mytilus edulis may become parasitized in either of two ways. First, by the larvae of Mytilicola being distributed by tidal and other currents. Secondly, by the introduction of adult or post-metamorphic Mytilus which are already parasitized.

The range over which the first method may operate will be limited by the period of free larval life, which appears to be short. If the observations made here are reliable as an indication of natural development, the truly planktonic phase lasts only 3 or 4 days and the copepodid larvae then begin to move downward in the water. The total free life is IO-I4 days. If during this time the larvae are dispersed to areas with a low incidence of Mytilus there may be no effective spreading of the parasite.

All the facts known at present show that only sexual reproduction can occur, and it involves the presence of the two sexes in one host. It may be significant that in the following samples showing a low incidence of infection only a single parasite was recorded in any one host.

$\begin{array}{lcc}\text { Site } & \begin{array}{c}\text { Infected } \\ \text { hosts }\end{array} & \begin{array}{c}\text { Total } \\ \text { sample }\end{array} \\ \text { Cattewater, Plymouth } & 4 & \text { II3 } \\ \text { Plymouth Sound } & 9 & 215 \\ \text { Brixham } & \text { I4 } & \text { I52 } \\ \text { Paignton } & 2 & 36 \\ \text { Exmouth } & \text { I } & \text { I50 }\end{array}$

A slightly higher number was found at Mudeford, at the mouth of the Hampshire River Avon where, from a total of forty-five Mytilus, sixteen were found to harbour twenty-three parasites. Mudeford is not far away from either Poole Harbour or Southampton Water, either of which could act as a source of infection. No such sources are known in the neighbourhood of either Exmouth, Paignton or Brixham, but the survey of this area is not yet completed and no mussels have been examined from the Dart estuary. 
The mussel colonies of the Tamar and Lynher estuaries, Plymouth Sound and the Cattewater show striking differences of infection which call for explanation. In each area quite dense colonies are to be found, though rather less in the Cattewater. Ten mussels taken at random at Anthony Quay (River Lynher) contained II 5 parasites of which thirty-nine were females carrying egg-sacs. We might expect the production of larvae from this area to be sufficient to infect rapidly all mussels in the Sound, but this has not yet occurred. In the Lynher and Tamar the mussels are on flat beds of mud and stones; in the Sound all are on steep or vertical surfaces free of mud, and in the Cattewater most of the mussels were taken from crevices in the quay walls and none were found by dredging.

It is suggested that because of the sinking effect in the infective copepodid stage mussels on the bottom are much more susceptible to infection than those raised on steep surfaces. Experiments are now being started at Southampton to test the relative rates of infection of buoyed and bottomliving groups of mussels. The evidence afforded by the material from Brixham is inconclusive, but not encouraging to this hypothesis. From a floating pontoon I34 mussels were examined, and thirteen were infected, each with a single parasite. Very few mussels were to be found on the sea-bed in this area, and only one out of eighteen was infected.

The spreading of Mytilicola by introduction of infected Mytilus may occur accidentally on driftwood or on shipping, or by the deliberate importation of mussels where they are used for bait. It appears most likely that shipping across the North Sea has introduced the parasite to harbours and estuaries along our eastern and southern coasts, and into Eire. Yet some have remained relatively free (Exmouth and Fowey) which are visited by a moderate amount of coastal traffic, while others (Yealm River) have a heavy infection and little or no shipping. Where Mytilus is used either for food or as bait the introduction of specimens from another port would be rash unless it were accompanied by a very careful examination for Mytilicola.

\section{EFFECT UPON THE HOST}

Caspers could not find any direct evidence of a harmful effect upon the host, but he records that the rate of filtration of water was reduced. It would be reasonable to suppose that an individual harbouring eight or ten parasites, which are common numbers, must suffer some deprivation of food. Taken as a whole, I have the impression that the parasitized stocks are less well nourished, but I have seen a specimen, apparently in normal condition, that contained a female Pinnotheres and twenty-seven Mytilicola.

The subject is being investigated at the Fisheries Experiment Station, Conway, and Dr Cole informs me in a personal communication, that where parasites are abundant severe loss of condition followed by death may result. 
The numbers of Mytilus have been greatly reduced in the Tamar off Neal Point during recent years, but until my observations in 1948 the parasite had not been recorded there. I detect a slight reduction in the Mytilus population at Woolston, Southampton, over the last 7 years, but could not attribute this to the parasite. Sections of the infected intestine do not reveal any damage to the tissues.

\section{SUMMARY}

Mytilicola intestinalis, a copepod parasite of Mytilus edulis, is now widespread along the English south coast.

The mouthparts are redescribed, and the loss of mandibles suggested by Dollfus is confirmed by the discovery of both mandibles and maxillules in the second parasitic larval stage.

Mytilicola is a comparatively recent immigrant. It has achieved a very high density of infection in harbours and estuaries, but also occurs in exposed and fully marine situations.

Factors influencing the distribution are discussed, and the infection of further estuarine populations of mussels is considered likely.

Owing to the behaviour of the infective copepodid larvae it is suggested that the parasite may be slow to colonize mussels that are raised above the sea-bed. This hypothesis is to be tested by experiment.

\section{REFERENCES}

CASPERS, H., I939. Über Vorkommen und Metamorphose von Mytilicola intestinalis Steuer (Copepoda paras.) in der südlichen Nordsee. Zool. Anz., Bd. I26, pp. I6I$7 \mathrm{I}$.

Claus, C., I895. Über die Maxillarfüsse der Copepoden. Arb. Zool. Inst. Wien., Bd. II, pp. 49-64.

EllenBy, C., 1947. A copepod parasite of the mussel new to the British fauna. Nature, Vol. I59, pp. 645-6.

Monod, T. \& Dollfus, R. P., I932. Les Copépodes parasites de mollusques. Ann. Paras. Hum. Comp., Vol. IO, pp. 129-204, 295-9.

Pesta, O., 1907. Die Metamorphose von Mytilicola intestinalis Steuer. Zeitschr.f. Wiss. Zool., Bd. 88, pp. 78-98.

SteuER, A., r902. Mytilicola intestinalis n.gen. n.sp. aus dem Darme von Mytilus galloprovincialis Lam. (Vorläufige Mitteilung). Zool. Anz., Bd. 25, pp. 635-7.

- 1905. Mytilicola intestinalis n.gen. n.sp. Arb. Zool. Inst. Wien, Bd. I5, pp. I-46.

Wilson, C. B., I9Io. The classification of the copepods. Zool. Anz., Bd. 35, pp. 60920. 